\title{
ResearchArticle
}

\section{Effect of seed coating on seed quality and yield of soybean [Glycine max (L.) Merrill]}

\author{
H.V. Kalpande, P.S. Chavan, S.B. Borgaonkar and A. B. Bagade
}

\section{SUMMARY}

An investigation on effect of seed coating on seed quality and yield of soybean [Glycine max (L).Merrill] was conducted during Kharif 2018 at Instructional Farm, Department of Agriculture Botany, Vasantrao Naik Marathwada Agriculture University, Parbhani. The experiment was laid out in Randomized Block Design with three replications and seven treatments viz., $\mathrm{T}_{1}$-Untreated seeds, $\mathrm{T}_{2}$-Polymer coating, $\mathrm{T}_{3}-\mathrm{T}_{2}+$ Vitavax, $\mathrm{T}_{4}-\mathrm{T}_{3}+\mathrm{GA}_{3}$ 100ppm, $\mathrm{T}_{5}-\mathrm{T}_{3}+\mathrm{CCC} 100 \mathrm{ppm}, \mathrm{T}_{6}-\mathrm{T}_{3}+\mathrm{NAA} 50 \mathrm{ppm}$, $\mathrm{T}_{7}-\mathrm{T}_{3}+\mathrm{IAA} 50 \mathrm{ppm}$. The experiment was conducted to study effect of different seed coating treatments such as seed on quality and yield of soybean. From the present investigation it was observed that $\mathrm{T}_{4}\left(\mathrm{~T}_{3}+\mathrm{GA}_{3}\right) 100 \mathrm{ppm}$ followed by $\mathrm{T}_{6}$ $\left(\mathrm{T}_{3}+\mathrm{NAA} 50 \mathrm{ppm}\right)$ and $\mathrm{T}_{7}-\left(\mathrm{T}_{3}+\mathrm{IAA}\right) 50 \mathrm{ppm}$, recorded higher seed quality and yield contributing traits. Mean days for 50 per cent flowering and mean days to harvest found non-significant. Treatment $T_{4}-\left(T_{3}+G_{3} 100 p p m\right)$ found superior in increasing plant height over treatment $T_{5}-\left(T_{3}+C C C 100 p p m\right)$.In treatment $T_{4}-\left(T_{3}+G_{3}\right) 100 p p m$ was found superior for number of branches, leaf area content, chlorophyll content, number of pods per plant, number of seed per pod. Yield per plot and per ha., test weight, harvest index followed by treatments $\mathrm{T}_{6}-\left(\mathrm{T}_{3}+\mathrm{NAA} 50 \mathrm{ppm}\right)$ and $\mathrm{T}_{7}-\left(\mathrm{T}_{3}+\mathrm{IAA} 50 \mathrm{ppm}\right.$ than all other seed coating treatments over the control. Biochemical studies found that, oil content and protein content higher in $\mathrm{T}_{7}-\left(\mathrm{T}_{3}+\mathrm{IAA} 50 \mathrm{ppm}\right)$ followed by treatments $\mathrm{T}_{6}-\left(\mathrm{T}_{3}+\mathrm{NAA} 50 \mathrm{ppm}\right)$ and $\mathrm{T}_{5}-\left(\mathrm{T}_{3}+\mathrm{CCC} 100 \mathrm{ppm}\right)$ than all other coating treatments over the control. Seed germination (\%), seed moisture (\%), plant total dry weight, was significantly in treatment $\mathrm{T}_{4}-\left(\mathrm{T}_{3}\right.$ $\left.+\mathrm{GA}_{3} 100 \mathrm{ppm}\right)$ followed by treatments $\mathrm{T}_{6}-\left(\mathrm{T}_{3}+\mathrm{NAA} 50 \mathrm{ppm}\right)$ and $\mathrm{T}_{7}-\left(\mathrm{T}_{3}+\mathrm{IAA} 50 \mathrm{ppm}\right)$ than all other seed coating treatments over the untreated seed.

Key Words : Seed quality, $\mathrm{GA}_{3}$, Seed germination, IAA, Protein content

How to cite this article : Kalpande, H.V., Chavan, P.S., Borgaonkar, S.B. and Bagade, A.B. (2020). Effect of seed coating on seed quality and yield of soybean [Glycine max (L.) Merrill]. Internat. J. Plant Sci., 15 (2): 116-120, DOI: 10.15740/HAS/IJPS/15.2/116120,Copyright@ 2020: Hind Agri-Horticultural Society.

Article chronicle : Received : 15.02.2020; Revised : 23.05.2020; Accepted : 16.06.2020

$\longrightarrow$ MEMBERS OF THE RESEARCH FORUM

Author to be contacted :

S. B. Borgaonkar, Upland Paddy Research Scheme, Vasantrao Naik

Marathwada Krishi Vidyapeeth, Parbhani (M.S.) India

Email : borgaonkars@rediffmail.com

Address of the Co-authors:

H. V. Kalpande, Department of Agriculture Botany, Vasantrao Naik

Marathwada Krishi Vidyapeeth, Parbhani (M.S.) India

P. S. Chavan, Agricultural School, Aurangabad (M.S.) India

$\overline{\text { A. B. Bagade, National Agricultural Research Project, Aurangabad }}$ (M.S.) India 